\title{
Assessment of Dong Quai Hepatic Metabolism and Potential Interactions when Combined with Chemotherapy
}

Xue Zhang ${ }^{1}$, Anjali Gaikwad ${ }^{1}$, Lata Mathew², Larry Coffer ${ }^{2}$, John Dalrymple ${ }^{3}$ and Judith A Smith ${ }^{1-3 *}$

${ }^{1}$ Department of Gynecologic Oncology and Reproductive Medicine, The University of Texas M.D. Anderson Cancer Center, Houston, Texas, USA ${ }^{2}$ Division of Pharmacy, The University of Texas M.D. Anderson Cancer Center, Houston, Texas, USA

${ }^{3}$ Department of Obstetrics, Gynecology and Reproductive Sciences, The University of Texas Health Science Center at Houston Medical School at Houston, Houston, Texas, USA

\begin{abstract}
Background: Dong Quai is a common herbal supplement classified as a "phytoestrogen" used for the improvement of female reproductive function. In the oncology setting, women often seek natural approaches for managing symptoms associated with decreased hormone levels either from surgery or chemotherapy-induced. Clinically, the concern is the safety of phytoestrogens in combination with chemotherapy. The objective of this study was to characterize the hepatic metabolism of Dong Quai to define the potential for drug interactions with selected chemotherapy agents and its impact on alterations in the cytotoxicity in panel of human cancer cell lines.
\end{abstract}

Methods: In vitro high through-put cytochrome P450 (CYP450) inhibition assay was performed for CYP450 2C9, 2C8, 2D6 and 3A4 isoenzymesto evaluate phase I metabolism of Dong Quai alcohol-free extract. An ex vivo hepatic induction assay with human hepatocytes was used to determine whether Dong Quai is an inducer of CYP450 isoenzymes. The potential cytotoxic effects of Dong Quai alone and its effect when combined with selected chemotherapies were evaluated by a growth inhibition assay in a panel of eight human cancer cell lines.

Results: No inhibition of CYP450 was observed in presence of Dong Quai. At an estimated clinical relevant concentration of $0.86 \mathrm{mg} / \mathrm{mL}$, Dong Quai demonstrated Quai induced CYP3A4, 2C9, 2C8 and 2D6. Dong Quaidid not demonstrated cytotoxicity by itself in the panels of eight human cancer cell lines with $50 \%$ growth inhibition was not achieved. The $25 \%$ growth inhibition was achieved at concentrations ranging from $0.39 \mathrm{mg} / \mathrm{mL}$ to $4.48 \mathrm{mg} / \mathrm{mL}$. Combination growth inhibition assays showed decreased cytotoxic activity of chemotherapy agents.

Conclusion: This data suggests that Dong Quai is an inducer of the CYP450 pathways and also decreased cytotoxic activity of selected chemotherapy. Until confirmatory in vivo information available Dong Quai should be used with caution with chemotherapy.

Keywords: Dong Quai; Cytochrome P450; Phytoestrogen; Metabolism; Cancer; Chemotherapy; Drug interactions

\section{Introduction}

Herbal and nutritional supplements have become very popular form of the Complementary Alternative Medicine (CAM) used to enhance health, disease prevention, and as "natural" alternatives to treat a number of the symptoms including hot flashes, decrease libido, vaginal dryness or insomnia associated with conditions with hormone imbalances such as menopause. Historically, synthetic hormones products have been prescribed together as Hormone Replacement Therapy (HRT) to manage the symptoms associated with menopause. Since its inception, the use of HRT in postmenopausal women in western countries has consistently increased over time until the concerning reports from five large randomized trials that evaluated HRT therapy in over 40,000 women that led to developments of clinical controversy on its role in management of menopause [1-6]. The major conclusions from all five of these trials was a significant and potentially fatal risk of using HRT for more than five years, including an increased incidence of breast cancer, stroke, and pulmonary embolism [1-6]. The Women's Health Initiative study was the largest amongst these studies, randomizing 16,608 women to HRT versus placebo that an interim analysis found there was an increased risk of breast and endometrial cancer, as well as significant increase risk thromboembolism associated with long-term use of HRT and lead to early closure of this study [3]. The symptoms of menopause are not life-threatening but can have quite the impact on quality of life and daily routines. Hence many women have sought natural alternatives to HRT specifically the herbal supplements classified as phytoestrogens.
Phytoestrogen is a term used to describe a group of natural products with a historic use for conditions that are now treated by exogenous estrogens. In general, phytoestrogens are biologically active compounds of plant origin with proposed estrogenic activity, evident by reported data to control menopausal symptoms such as hot flushes and mood swings. There are over eighteen phytoestrogen products based their plant family names in current consumers market. This study focused on one of the most commonly used phytoestrogen, Dong Quai, which if found in many combination herbal supplement products designed for women to use to manage hormone-related symptoms. Dong Quai also known as Angelica sinensis is a perennial herb native to China, Japan, and Korea. For thousands of years in traditional Far Eastern medicine, Dong Quai has been widely used for correcting menstrual disorders and other hormone-related symptoms and is often combined with other herbs $[7,8]$.

*Corresponding author: Judith A Smith, Department of Obstetrics, Gynecology and Reproductive Sciences, 6431 Fannin Street, Houston, Texas 77030, USA, Tel: 713-500-6408; Fax: 713-500-5474; E-mail: Judith.Ann.Smith@uth.tmc.edu

Received October 10, 2013; Accepted November 16, 2013; Published November 20, 2013

Citation: Zhang X, Gaikwad A, Mathew L, Coffer L, Dalrymple J, et al. (2013) Assessment of Dong Quai Hepatic Metabolism and Potential Interactions when Combined with Chemotherapy. J Integr Oncol 2: 108. doi:10.4172/23296771.1000108

Copyright: $\odot 2013$ Zhang X, et al. This is an open-access article distributed unde the terms of the Creative Commons Attribution License, which permits unrestricted use, distribution, and reproduction in any medium, provided the original author and source are credited. 
Current pre-clinical and clinical studies on the safety of phytoestrogens like Dong Quai are very conflicting. While in some preclinical in vitro studies phytoestrogens have been reported to stimulate cancer cell growth, this has often not been confirmed with in vivo or clinical studies. While some preclinical studies in vitro studies showed that Dong Quai significantly stimulated the proliferation of MCF-7 cells, clinically use of Dong Quai has been deemed safe but not always effective [9-11]. Part of the contributing factors for the conflicting data is the inconsistency in dosing, specifically using doses in preclinical studies that is unachievable, magnitudes of concentrations that could be achieved in humans. To date though, there is very limited if any pharmacokinetic data available for any of the phytoestrogens including Dong Quai. Thus, in these studies an "estimated clinically relevant dose" was used. This concentration assumes $100 \%$ bioavailability in an average $70 \mathrm{~g}$ adult with $7 \mathrm{~L}$ volume of distribution. It is not exact, but was deemed appropriate concentration to use to evaluate the metabolism of Dong Quaiand to evaluate the drug interaction between Dong Quai and several selected chemotherapy agents including the potential impact oncytotoxicity of Dong Quai with or without chemotherapy in a panel of human cancer cell lines. The long term goal of this study is to contribute to the investigation to identify a safe and effective phytoestrogen to manage hormone-related symptoms in women with cancer receiving active chemotherapy treatment.

\section{Materials and Methods}

\section{High throughput cyp450 inhibition assays}

The protocol was adapted from a validated method from BD Gentest (Woburn, MA), the High Throughput Method for Measuring CYP450 Inhibition (version 4.2, 2000) $[12,13]$. Dong Quai was diluted in deionized water. Acetonitrile was used as solvent to dissolve the positive controls (ketoconazole, quercetin, sulfaphenazole, and quinidine) and substrates [dibenzylfluorescin (DBF) and 3-[2-N,Ndiethyl-N-methylammonium) ethyl]-7-methoxy-4-methylcoumarin iodide (AMMC)] (Table 1). Working solutions were made by dilution in $0.5 \mathrm{M}$ potassium phosphate buffer, $\mathrm{pH}$ 7.4. Assays were conducted in 96-well black bottom microtiter plates. The final cofactor concentrations were $1.3 \mathrm{mM} \mathrm{NADP}{ }^{+}, 3.3 \mathrm{mM}$ glucose-6-phosphate, and $0.4 \mathrm{U} / \mathrm{mL}$ glucose-6-phosphate dehydrogenase, and $3.3 \mathrm{mM}$ magnesium ion. Final incubation volume for each well was $0.2 \mathrm{~mL}$. After the addition of inhibitor positive control vehicles or Dong Quai at a maximum concentration of $0.86 \mathrm{mg} / \mathrm{mL}$ was added (Dong Quai ranged from 0.86 down to $0.00039 \mathrm{mg} / \mathrm{mL}$ ) (Table 1). The $0.86 \mathrm{mg} /$ $\mathrm{mL}$ concentration was selected as an estimate of the clinical relevant concentration based on the current maximum recommended dosage

\begin{tabular}{|l|l|l|l|l|l|}
\hline $\begin{array}{l}\text { CYP450 } \\
\text { inhibitor }\end{array}$ & $\begin{array}{l}\text { Fluorometric } \\
\text { substrate }\end{array}$ & $\begin{array}{l}\text { Excitation/ } \\
\text { Emission } \\
\text { wavelength } \\
\text { (nm) }\end{array}$ & $\begin{array}{l}\text { CYP450 } \\
\text { pathway } \\
\text { inhibited }\end{array}$ & $\begin{array}{l}\text { Inhibitor } \\
\text { concentration }\end{array}$ & $\begin{array}{l}\text { Reaction } \\
\text { time }\end{array}$ \\
\hline Ketoconazole & DBF & $485 / 528$ & $3 \mathrm{~A} 4$ & 0 to $7.5 \mu \mathrm{M}$ & 60 minutes \\
\hline Quercetin & DBF & $485 / 528$ & $2 \mathrm{C} 8$ & 0 to $15 \mu \mathrm{M}$ & 60 minutes \\
\hline Sulfaphenazole & DBF & $485 / 528$ & $2 \mathrm{C} 9$ & 0 to $15 \mu \mathrm{M}$ & 60 minutes \\
\hline Quinidine & AMMC & $360 / 460$ & $2 \mathrm{D} 6$ & 0 to $0.75 \mu \mathrm{M}$ & 60 minutes \\
\hline
\end{tabular}

Four major CYP450 isoenzymes were selected to determine if Dong Quai is an inhibitor of this system. Ketoconazole, quercetin, sulfaphenazole, and quinidine are known inhibitors of the 4 isoenzymes, here used as positive controls at $100 \mu \mathrm{M}$. CYP450 isoenzymes transform substrates (DBF and AMMC) to fluorescein metabolites, generating strong signals monitored at responsive excitation/emission wavelengths by FL600 Dual-Band plate reader. The total incubation time was 60 minutes.

Table 1: Positive control inhibitors used in the in vitro CYP450 metabolism inhibition study.

\begin{tabular}{|l|l|l|l|}
\hline CYP450 substrate & CYP450 pathway & $\begin{array}{l}\text { Substrate } \\
\text { concentration }\end{array}$ & Wavelength (nm) \\
\hline Diclofenac & 2C8/2C9 & $100 \mu \mathrm{M}$ & 280 \\
\hline Dextromethorphan & 2D6 & $100 \mu \mathrm{M}$ & 280 \\
\hline Docetaxel & 3A4 & $100 \mu \mathrm{M}$ & 230 \\
\hline Dong Quai & Test & $0.86 \mathrm{mg} / \mathrm{mL}$ & ex360/em460 \\
\hline
\end{tabular}

In CYP450 induction assay, Diclofenac, Dextromethorphan and Docetaxel were used as substrates of different isoenzymes. The substrates were added after 3 day induction of hepatocytes. Working concentrations and wavelength of UV absorption of the substrates are listed. To determine if Dong Quai is a substrate of CYP450 system, it was added in a separate plate in parallel with other substrates. Excitation and emission wavelength of Dong Quai was 360 and $460 \mathrm{~nm}$ respectively.

Table 2: CYP450 substrates used in the ex vivo hepatocyte induction assay.

of 6 gram daily as instructed by the manufacturer, assuming $100 \%$ bioavailability, and $7 \mathrm{~L}$ as the estimated total blood volume of an average adult. Respective enzyme and substrate mixtures (DBF at $100 \mu \mathrm{M}$ or $\mathrm{AMMC}$ at $500 \mu \mathrm{M})$ were added to the reaction mixture as appropriate. In each reaction well there were 5, 4, 2 or 1.5 pmol present of CYP450 3A4, 2C8, 2C9, and 2D6, respectively. After one hour incubation at $37^{\circ} \mathrm{C}$, reactions were stopped with $75 \mu \mathrm{L} 2 \mathrm{mM}$ sodium hydroxide or 80:20 acetonitrile: tris base solution for CYP450 2D6 only. The extent of CYP450 inhibition was evaluated by comparing the metabolism of varied concentrations in the presence and absence of the known inhibitor. The amount of product metabolized for the control comparison reactions was measured with FL600 Dual-Band plate reader from BioTek Instruments, Inc. (Winooski, VT) using fluorescence emission detection at $528 \mathrm{~nm}$ (excitation $485 \mathrm{~nm}$ ) of fluorescein (metabolite product of DBF metabolism by CYP450) or at $460 \mathrm{~nm}$ (excitation 360) of 3-[2-(N, N-diethyl-N-methyl ammonium) ethyl]-7-hydroxy-4-methylcoumarin (AMHC) (metabolite of AMMC).

\section{Hepatic metabolism induction assay}

Cryopreserved human hepatocytes were purchased from BD Biosciences (Gentest ${ }^{\mathrm{TM}}$ ): Discovery Labware (Woburn, MA). Hepatocytes were allowed to seed for 2 to 4 hours with Hepatozyme SFM media $\left(\right.$ Gibco $^{\mathrm{TM}}$ Invitrogen Corporation, Carlsbad, CA), containing $10 \%$ fetal bovine serum (Gemini Bio-Products, West Sacramento, CA) and $250 \mu \mathrm{M}$ ascorbic acid (Sigma-Aldrich, St. Louis, $\mathrm{MO})$. After adherence was achieved the hepatocytes were maintained in un-supplemented Hepatozyme media and were incubated for 72 hours at $37^{\circ} \mathrm{C}\left(5 \% \mathrm{CO}_{2}\right)$ to allow recovery before use. An ex vivo human metabolism model was used to determine if Dong Quai is able to induce isoenzyme CYP450 3A4, 2C8/2C9, or 2D6. Known substrates for each isoenzymes were used including docetaxel (CYP450 3A4), diclofenac (CYP450 2C8/2C9), and dextromethorphan (CYP450 2D6) (Table 2). The assay was performed in quadruplicate comparing Dong Quai $0.86 \mathrm{mg} / \mathrm{mL}$ with a control inducer, rifampicin $25 \mu \mathrm{M}$ (Sigma-Aldrich, St. Louis, MO) Hepatocytes were induced for 72 hours with either rifampicin or Dong Quai which was supplemented in fresh media every 24 hours. The substrate control treated hepatocytes were supported with only media changes every 24 hours. After 72 hours, rifampicin and Dong Quai were removed and the appropriate concentration of substrate (specific to the CYP450 isoenzyme of interest) was added or Dong Quai as test substrate was added (Table 2). Samples from time 0, $2,4,6$, and 24 hours were obtained in UV-Vis 96 -well plates for CYP450 2C8/2C9, 3A4 and CYP450 2D6 and absorbance were read at 280 $\mathrm{nm}$ (Diclofenac and Dextromethorphan) or $230 \mathrm{~nm}$ (Docetaxel). To identify if Dong Quai metabolism was induced by rifampicin or Dong Quai extract itself, black 96-well plate was used and detected at $360 \mathrm{~nm}$ (excitation) $460 \mathrm{~nm}$ (emission) for fluorescent signal alteration. 


\section{Chemicals and drugs}

Dong Quai alcohol-free fluid extract was available in $1000 \mathrm{mg} /$ $\mathrm{mL}$ solution and was purchased from Nature's Answer (Hauppauge, NY). Quercetin, Quinidine, Ketoconazole, Sulfaphenazole, Dibenzyl Fluorescin (DBF), AMMC, potassium phosphate monobasic, potassium phosphate dibasic, $\mathrm{NADP}^{+}$, glucose-6-phosphate, glucose6-phosphate dehydrogenase, magnesium chloride hexahydrate, sodium citrate, tribasic, and acetonitrile were all obtained from SigmaAldrich (St. Louis, MO). Tris base and 96-well micro titer plates (black/ clear bottom) were purchased from Fisher Scientific (Pittsburgh, $\mathrm{PA}$ ). CYP450 3A4, 2C8, 2C9, and 2D6 isoenzymes microsomes were purchased from BD Biosciences (Gentest ${ }^{\mathrm{TM}}$, Bedford, MA) and they were stored at $-80^{\circ} \mathrm{C}$ until analysis and used according the supplier's bulletin. Dimethyl Sulphoxide (DMSO) and 3-(4,5-cimethylthiazol2-yl)-2,5-diphenyl Tetrazolium bromide (MTT) were purchased from Sigma-Aldrich Co. (St. Louis, MO). Commercial grade chemotherapy agents were used including: carboplatin (SICOR Pharmaceuticals, Irvine, CA), doxorubicin $\mathrm{HCl}$ (lyophilized, Ben Venue Laboratories, Inc., Bedford, $\mathrm{OH}$ ), gemcitabine (GEMZAR ${ }^{\circledR}$, Eli Lilly and Company, Indianapolis, IN), paclitaxel (TAXOL ${ }^{\circledR}$, Bristol-Myers Squibb Company, Princeton, NJ) and topotecan (HYCAMTIN ${ }^{\circledR}$, GlaxoSmithKline, Research Triangle Park, NC)

\section{Cell culture}

A panel of human carcinoma cell lines was selected based on Estrogen Receptor (ER) expression including: two ovarian cancer cell lines -SKOV3, TOV-112D; two endometrial cancer cell linesHEC-1B, Ishikawa; two cervical cancer cell lines-HeLa, $\mathrm{SiHa}$, and one breast cancer cell line, MCF-7, then the NCI-H23, a human non-small cell lung cancer, was included as a ER-negative control. All cell lines were obtained from the American Type Culture Collection (ATCC, Rockville, MD) and maintained for less than 10 passages. All cell lines were grown in $75 \mathrm{~cm}^{2}$ culture flasks in $5 \% \mathrm{CO}_{2}$ in air at $37^{\circ} \mathrm{C}$ to $90 \%$ confluence. The $75 \mathrm{~cm}^{2}$ culture flasks, serological pipettes, 96-well plates and other cell culture supplies were purchased from Fisher Scientific (Pittsburgh, PA).

The cell lines: HEC-1-B (endometrial adenocarcinoma), HeLa (cervical squamous carcinoma), and $\mathrm{SiHa}$ (cervical squamous carcinoma) were propagated in a medium consisting of minimum essential medium (MEM) (Eagle's) (Mediatech Inc., Manassas, VA) supplemented with non-essential amino acids (NEAA) and Earle's BSS adjusted to contain $1.0 \mathrm{mM}$ sodium pyruvate, $1.5 \mathrm{~g} / \mathrm{L}$ sodium bicarbonate, $2 \mathrm{mM}$ L-glutamine, $10 \% \mathrm{FBS}$, and $0.4 \%$ antibiotic solution (Antimycotic solution-10,000 I.U/mL Penicillin, 10,000 $\mu \mathrm{g} / \mathrm{mL}$ Streptomycin, $25 \mu \mathrm{g} / \mathrm{mL}$ Amphotericin B, Mediatech Inc., Manassas, VA 20109). The ovarian adenocarcinoma (SKOV-3) was propagated with media consisting of McCoy's 5 a media with $1.5 \mathrm{mM}$ L-glutamine, $10 \% \mathrm{FBS}$, and $0.4 \% \mathrm{~mL}$ antibiotics. The mixed adenocarcinomaendometroid cell line TOV-112D was propagated in a 1:1 mixture of MCDB 105 and medium 199 with 15\% FBS and 0.4\% mL antibiotics. The endometrial cell line Ishikawa was propagated with 1:1 mixture of DMEM: F12 (low glucose) with 10\% FBS. The MCF-7 cell line was propagated with EMEM with $2 \mathrm{mM}$ L-glutamine and Earle's BSS adjusted to contain $1.5 \mathrm{~g} / \mathrm{L}$ sodium bicarbonate, $0.1 \mathrm{mM}$ NEAA, 1.0 $\mathrm{mM}$ sodium pyruvate, $0.01 \mathrm{mg} / \mu \mathrm{L}$ bovine insulin, $10 \% \mathrm{FBS}$, and $1 \%$ antibiotics The NCI-H23 cell line was propagated with RPMI 1640 with $2 \mathrm{mM}$ L-glutamine, $10 \mathrm{mM}$ Hepes, $1 \mathrm{mM}$ sodium pyruvate, $4.5 \mathrm{~g} / \mathrm{L}$ glucose, $1.5 \mathrm{~g} / \mathrm{L}$ sodium bicarbonate, $10 \% \mathrm{FBS}$, and $1 \%$ antibiotics.

\section{Growth inhibition assays}

Growth inhibition assays were performed to determine the cytotoxic activity of Dong Quai alone and in combination with selected chemotherapy agents. Cells were plated to achieve 2,500-5,000 cells per well and incubated at $37^{\circ} \mathrm{C}$ for 24 hours before treatment. Cells were treated with concentrations ranging from $0.017-8.6 \mathrm{mg} / \mathrm{mL}$ of Dong Quai alone using respective cell media as the diluents for dilutions. Control wells had no drug and media alone and blank wells had no cells, drug, or media. A $3 \mathrm{mg} / \mathrm{mL}$ stock solution of MTT was prepared using Phosphate-Buffered Saline (PBS). After 72 hours incubation period, $25 \mu \mathrm{L}$ of 3-(4,5-dimethylthiazol-2-yl)-2,5-diphenyl tetrazolium bromide (MTT) was added to obtain a final concentration of $0.3 \mathrm{mg} /$ $\mathrm{mL}$ per well, and cells were further incubated for 2 hours at $37^{\circ} \mathrm{C}$. The plates were centrifuged and the supernatant was removed. $50 \mu \mathrm{L}$ of DMSO was added to all wells and absorbency was measured at $562 \mathrm{~nm}$. The inhibitory concentration to achieve $10 \%$ cell death $\left(\mathrm{IC}_{10}\right), \mathrm{IC}_{25}$, and $\mathrm{IC}_{50}$ of Dong Quai for each cell line was calculated. All experiments were done in triplicate for each cell line and drug combination.

To evaluate the potential of Dong Quai to impact the cytotoxic activity, growth inhibition assays were completed with selected commonly used chemotherapy agents including: carboplatin, doxorubicin, gemcitabine, paclitaxel, and topotecan in combination with Dong Quai. The $\mathrm{IC}_{50}$ of each anticancer agent was administered alone and in combination with selected clinically relevant concentration $0.86 \mathrm{mg} / \mathrm{mL}$ of Dong Quai. Each drug combination was completed in quadruplicate and the experiments were repeated in triplicate. The assessment of drug synergy was done using an isobolar method and the interaction index for each combination for each cell line was calculated. The index, denoted by $\gamma$ is defined by the isobolar relation $\mathrm{a} / \mathrm{A}+\mathrm{b} / \mathrm{B}=\gamma$ where $\mathrm{A}$ and $\mathrm{B}$ are the doses of drug $\mathrm{A}$ (alone) and $B$ (alone), respectively, that give the specified effect and $(a, b)$ is the combination dose that produces this effect level. For each combination mean dose values were used in the equation to determine the mean interaction index. The quantities in this equation were obtained from the dose response curves of drugs used in each combination. If $\gamma=1$ the interaction is additive; if $\gamma$ is less than one it is super-additive (synergistic), and if $\gamma$ is greater than one it is sub-additive (antagonistic) [14]. After determining Interaction Index in each cell line, the mean Interaction Index for panel of cancer cell lines was determined for each drug.

\section{Results}

At the estimated clinically relevant concentration of $0.86 \mathrm{mg} / \mathrm{mL}$, Dong Quai did not demonstrate inhibition of the CYP450 2C8, 2C9, $3 \mathrm{~A} 4$, or 2D6 pathways in in vitro CYP450 inhibition assays. The ex vivo hepatic metabolism induction assay, using cryo preserved human hepatocytes, after treatment with Dong Quai $0.86 \mathrm{mg} / \mathrm{mL}$ induction of CYP450 2C8, 2C9, 2D6 and 3A4 was observed. For instance, at 2 hours, Dong Quai caused 27.18\% induction compared with $25.17 \%$ induction

\begin{tabular}{|c|c|c|}
\hline Cytochrome P450 isoenyzme & Inhibitor & Inducer \\
\hline 3A4 & - & + \\
\hline 2C8 & - & + \\
\hline 2C9 & - & + \\
\hline 2D6 & - & + \\
\hline
\end{tabular}

In the in vitro inhibition assay, Dong Quai didn't exhibit any inhibition effect on any of the four isoenzymes. However in the ex vivo human hepatocytes, Dong Quai induced CYP3A4, 2C9, 2C8 and 2D6 at clinically relevant concentration $0.86 \mathrm{mg} /$ $\mathrm{mL}$ and was comparable to the control inducing agent, rifampin.

Table 3: Result of inhibition assay and induction assay results. 
Citation: Zhang X, Gaikwad A, Mathew L, Coffer L, Dalrymple J, et al. (2013) Assessment of Dong Quai Hepatic Metabolism and Potential Interactions when Combined with Chemotherapy. J Integr Oncol 2: 108. doi:10.4172/2329-6771.1000108

Page 4 of 5

\begin{tabular}{|c|c|c|c|c|c|}
\hline Cell lines & $\begin{array}{l}\text { Dong Quai + } \\
\text { Carboplatin }\end{array}$ & $\begin{array}{l}\text { Dong Quai + } \\
\text { Doxorubicin }\end{array}$ & $\begin{array}{l}\text { Dong Quai + } \\
\text { Gemcitabine }\end{array}$ & $\begin{array}{l}\text { Dong Quai + } \\
\text { Paclitaxel }\end{array}$ & $\begin{array}{l}\text { Dong Quai + } \\
\text { Topotecan }\end{array}$ \\
\hline TOV-112D & $\begin{array}{l}2.44 \\
\text { Antagonistic }\end{array}$ & \begin{tabular}{|l|}
1.77 \\
Antagonistic
\end{tabular} & $\begin{array}{l}0.97 \\
\text { Synergistic }\end{array}$ & $\begin{array}{l}2.02 \\
\text { Antagonistic }\end{array}$ & $\begin{array}{l}1.91 \\
\text { Antagonistic }\end{array}$ \\
\hline SKOV $_{3}$ & $\begin{array}{l}0.94 \\
\text { Synergistic }\end{array}$ & $\begin{array}{l}2.25 \\
\text { Antagonistic }\end{array}$ & $\begin{array}{l}1.48 \\
\text { Antagonistic }\end{array}$ & $\begin{array}{l}2.25 \\
\text { Antagonistic }\end{array}$ & $\begin{array}{l}2.25 \\
\text { Antagonistic }\end{array}$ \\
\hline HeLa & $\begin{array}{l}1.74 \\
\text { Antagonistic }\end{array}$ & $\begin{array}{l}2.41 \\
\text { Antagonistic }\end{array}$ & $\begin{array}{l}2.93 \\
\text { Antagonistic }\end{array}$ & $\begin{array}{l}0.92 \\
\text { Synergistic }\end{array}$ & $\begin{array}{l}1.41 \\
\text { Antagonistic }\end{array}$ \\
\hline $\mathrm{SiHa}$ & $\begin{array}{l}1.99 \\
\text { Antagonistic }\end{array}$ & $\begin{array}{l}1.48 \\
\text { Antagonistic }\end{array}$ & $\begin{array}{l}1.10 \\
\text { Antagonistic }\end{array}$ & $\begin{array}{l}1.27 \\
\text { Antagonistic }\end{array}$ & $\begin{array}{l}1.30 \\
\text { Antagonistic }\end{array}$ \\
\hline Ishikawa & $\begin{array}{l}2.13 \\
\text { Antagonistic }\end{array}$ & $\begin{array}{l}2.88 \\
\text { Antagonistic }\end{array}$ & $\begin{array}{l}1.46 \\
\text { Antagonistic }\end{array}$ & $\begin{array}{l}2.19 \\
\text { Antagonistic }\end{array}$ & $\begin{array}{l}2.00 \\
\text { Antagonistic }\end{array}$ \\
\hline HEC-1B & $\begin{array}{l}0.82 \\
\text { Synergistic }\end{array}$ & $\begin{array}{l}1.40 \\
\text { Antagonistic }\end{array}$ & $\begin{array}{l}1.18 \\
\text { Antagonistic }\end{array}$ & $\begin{array}{l}1.00 \\
\text { Additive }\end{array}$ & $\begin{array}{l}0.87 \\
\text { Synergistic }\end{array}$ \\
\hline MCF-7 & $\begin{array}{l}0.76 \\
\text { Synergistic }\end{array}$ & $\begin{array}{l}1.52 \\
\text { Antagonistic }\end{array}$ & $\begin{array}{l}1.41 \\
\text { Antagonistic }\end{array}$ & $\begin{array}{l}1.30 \\
\text { Antagonistic }\end{array}$ & $\begin{array}{l}1.65 \\
\text { Antagonistic }\end{array}$ \\
\hline $\mathrm{NCl}-\mathrm{H} 23$ & $\begin{array}{l}1.48 \\
\text { Antagonistic }\end{array}$ & $\begin{array}{l}1.48 \\
\text { Antagonistic }\end{array}$ & $\begin{array}{l}2.05 \\
\text { Antagonistic }\end{array}$ & $\begin{array}{l}0.92 \\
\text { Synergistic }\end{array}$ & $\begin{array}{l}1.36 \\
\text { Antagonistic }\end{array}$ \\
\hline $\begin{array}{l}\text { SUMMARY } \\
\text { Mean } \pm \text { SD }\end{array}$ & $\begin{array}{l}1.54 \pm 0.64 \\
\text { Antagonistic }\end{array}$ & $\begin{array}{l}1.90 \pm 0.55 \\
\text { Antagonistic }\end{array}$ & $\begin{array}{l}1.57 \pm 0.64 \\
\text { Antagonistic }\end{array}$ & $\begin{array}{l}1.48 \pm 0.58 \\
\text { Antagonistic }\end{array}$ & $\begin{array}{l}1.59 \pm 0.45 \\
\text { Antagonistic }\end{array}$ \\
\hline
\end{tabular}

Interaction Index $\mathrm{y}=\mathrm{a} / \mathrm{A}+\mathrm{b} / \mathrm{B}$. Eight human cancer cell lines were treated with the combination of a clinically relevant concentration of Dong $\mathrm{Quai}_{\text {and }} \mathrm{C}_{50}$ concentrations of five chemotherapy drugs. The combination evaluated demonstrated decreased growth inhibitory activity for all combinations in all cell lines. The Interaction Index $\gamma$, was calculated for each cell line and each combination and then summarized with mean Interaction Index. In summary, overall Dong Quai was antagonistic in combination with the chemotherapy agents evaluated.

Table 4: Summary of the Mean Interaction Index of Dong Quai with five chemotherapy drugs.

\begin{tabular}{|l|l|l|l|}
\hline Drug & Substrate & Inhibitor & Inducer \\
\hline Cyclophosphamide & $2 \mathrm{~B} 6$ & & \\
\hline Ifosfamide & $3 \mathrm{~A} 4$ & & \\
\hline Paclitaxel & $2 \mathrm{C} 8 / 2 \mathrm{C} 9,3 \mathrm{~A} 4$ & & $2 \mathrm{C} 8 / 2 \mathrm{C} 9$ \\
\hline Docetaxel & $3 \mathrm{~A} 4$ & & \\
\hline Tamoxifen & $2 \mathrm{C} 9,2 \mathrm{D} 6,3 \mathrm{~A} 4$ & & \\
\hline Letrozole & $2 \mathrm{~A} 6 / 3 \mathrm{~A} 4$ & & \\
\hline Irinotecan & $3 \mathrm{~A} 4$ & & \\
\hline Topotecan & $3 \mathrm{~A} 4$ & & \\
\hline Vincristine & $3 \mathrm{~A} 4$ & & \\
\hline Imatinib & $3 \mathrm{~A} 4$ & $3 \mathrm{~A} 4$ & \\
\hline Doxorubicin & $3 \mathrm{~A} 4$ & $2 \mathrm{D} 6$ & \\
\hline Epirubicin & $3 \mathrm{~A} 4$ & & \\
\hline
\end{tabular}

index for each combination of Dong Quai with chemotherapy drug was calculated for each cell line as described in materials and methods. While a few combinations demonstrated synergy in selected cell lines, overall Dong Quai have interaction index ranging from 1.481.9 , suggesting antagonistic activity with all the chemotherapy agents evaluated in the panel of ER+ human cancer cell lines. The interaction index data is summarized in Table 4.

\section{Discussion}

While exposure to Dong Quai was not associated with inhibition of any of the CYP450 isoenzyme hepatic metabolism pathways, induction of CYP4502C9, 2C8, 2D6 and 3A4 hepatic metabolism pathways was observed after exposure to estimated clinically relevant concentration of Dong Quai $0.86 \mathrm{mg} / \mathrm{dL}$. This indicates that Dong Quai may have a potential for drug interactions with drugs metabolized by these CYP450 isoenzyme hepatic metabolism pathways. Table 5 provides a list of commonly used chemotherapy agents that may interact with Dong Quai due to CYP450 induction of 2C9, 2C8, 2D6 and 3A4. This would be important to consider when make recommendations to combine use of Dong qui with other medications. Furthermore, the results of the growth inhibition assays indicated that Dong Quai had an overall antagonistic interaction with the cytotoxic activity standard chemotherapy agents in the panel of eight human cancer cell lines. While in a few cell lines there was observation of synergistic activity, this study was focusing on safety for making general recommendations for use of Dong Quai in combination with chemotherapy. Since tumors have inherent variability, a conservative approach to draw a conclusion for activity was based on antagonistic, additive or synergistic activity in the majority (four or more) of cell lines evaluated as well as determination the mean Interaction Index value. These finding are important because the combination of a potential drug-drug interaction involving CYP450 and antagonistic effect with standard chemotherapy agents suggests that Dong Quai would not be safe to use in cancer patients while receiving chemotherapy.

The findings in our study are consistent with finding from previous pre-clinical studies that used higher doses, what are unlikely 
Citation: Zhang X, Gaikwad A, Mathew L, Coffer L, Dalrymple J, et al. (2013) Assessment of Dong Quai Hepatic Metabolism and Potential Interactions when Combined with Chemotherapy. J Integr Oncol 2: 108. doi:10.4172/2329-6771.1000108

Page 5 of 5

clinically achievable concentrations, of Dong Quai but also observed potential tumor potentiation. For example an in vitro study showed that Dong Quai dose-dependently and significantly stimulated the proliferation of MCF-7 cells with a weak estrogen-agonistic activity in the presence of 17 beta-estradiol, as evidenced by the significant suppression by 4-hydroxytamoxifen [9]. While another study found Dong Quai enhanced the proliferation of breast cancer cell line MCF-7 independent of estrogen activity [15]. Thus the antagonistic interaction observed in this study could be attributed to direct cancer cell potentiation and not an interaction directly with the chemotherapy agent itself. However, the metabolism data still suggests potential for drug-herbal interaction as well. A good example to consider confirm metabolism contributing factor is that Dong qui is classified as a "phytoestrogen" and potentiation of growth has only been reported in estrogen-mediated cancer, however this study did observe antagonistic activity in the non-small cell lung cancer cell line as well.

As one of the most commonly used CAM agents for female reproductive function improvement, Dong Quai has become the study of interest of many investigators. Prior to evaluating it as potential herbal/ natural alternative to HRT for the management of hormone-mediated symptoms, it is necessary to define the pharmacology profile of Dong Quai in humans. In this study an estimated "achievable concentration" was used to define potential for drug-herbal interactions that assumes $100 \%$ bioavailability to give a "highest possible" relevant concentration which was better than arbitrarily selecting a dose to use in the studies. However, this is a limitation of this study because $100 \%$ bioavailability is unlikely with any compound/drug. Determining safety is a priority before starting further clinical study design, especially for use in women with estrogen mediated cancer or even strong family history of cancer. Pharmacokinetic study in healthy volunteers is being pursued to confirm the achievable Dong Quai concentration which will give better information for determining if it is a candidate for to be a safe and effective phytoestrogen to manage hormone-related symptoms in women with cancer receiving active chemotherapy treatment.

In conclusion, this data suggests that Dong Quai is an inducer of the CYP450 pathways and also decreased cytotoxic activity of selected chemotherapy. Keeping in spirit of "first does no harm", conservative recommendations are being made at this time based on the pre-clinical data available. However, the metabolism data still suggests potential for drug-herbal interaction as well. Until prospective pharmacology data in humans to determine what systemic plasma concentration of Dong qui is achievable and confirmatory in vivo information is available, Dong Quai should be used with caution in patients with cancer receiving chemotherapy.

\section{References}

1. Beral V, Banks E, Reeves G, Appleby A (1999) Use of HRT and the subsequent risk of cancer. J Epidemiol Biostat 4: 191-210.

2. Beral V, Banks E, Reeves G (2002) Evidence from randomized trials on the long-term effects of hormone replacement therapy. Lancet 360: 942-944.

3. Writing group for the Women's Health Initiative Investigators (2002) Risks and benefits of estrogen plus progestin in healthy postmenopausal women. Principle results from the women's health initiative randomized control trial. JAMA 288: 321-333.
4. Hulley S, Furberg C, Barrett-Connor E, Cauley J, Gardy D, et al. (2002) Noncardiovascular disease outcomes during 6.8 years of hormone therapy: Heart and estrogen/progestin replacement study follow-up (HERS II). JAMA 288: 58-66.

5. Viscoli CM, Brass LM, Keman WN, Sarrel PM, Suissa S, et al. (2001) A clinica trial of estrogen-replacement therapy after ischemic stroke. N Engl J Med 345: 1243-1249.

6. Hoibraaten E, Qvigstad E, Arnesen H, Larsen S, Wickstrom E, et al. (2000) Increased risk of recurrent venous Thromboembolism during hormone replacement therapy: results of the randomized, double-blind, placebo controlled estrogen in venous Thromboembolism trial (EVTET). Thromb Haemost 84: 961-967.

7. Al-Bareeq RJ, Ray AA, Nott L, Pautler SE, Razvi Het (2010) Dong Quai (Angelica sinensis) in the treatment of hot flashes for men on androgen deprivation therapy: results of a randomized double-blind placebo controlled trial. Can. Urol. Assoc. Can Urol Assoc J 4: 49-53.

8. Yeung KS, Gubili J (2009) Dong Quai (Angelica sinensis). J S Integr Oncol 7 : 121-22.

9. Lau CB, Ho TC, Chan TW (2005) Use of Dong Quai (Angelica sinensis) to treat peri- or postmenopausal symptoms in women with breast cancer: is it appropriate? Menopause 12: 734-740.

10. Rotem C, Kaplan B (2007) Phyto-Female Complex for the relief of hot flushes, night sweats and quality of sleep: randomized, controlled, double-blind pilot study. Gynecol Endocrinol 23: 117-122.

11. Hirata JD, Swiersz LM, Zell B, Small R, Erringer B (1997) Does Dong Quai have estrogenic effects in postmenopausal women? A double-blind, placebocontrolled trial. Fertil Steril 68: 981-986.

12. Crespi CL, Miller VP, Penman BW (1997) Microtiter plate assays from human, drug-metabolizing cytochrome P450s. Anal Biochem 248: 188-190.

13. Mach CM, Fugii H, Wakame K, Smith J (2008) Evaluation of Active Hexose Correlated Compound Hepatic Metabolism and Potential for Drug Interactions with Chemotherapy Agents. Journal of the Society for Integrative Oncology 6 : 105-09.

14. Ronald JT (2002) The interaction index: a measure of drug synergism. Pain 98: 163-168.

15. Amato P, Christophe S, Mellon PL (2002) Estrogenic activity of herbs commonly used as remedies for menopausal symptoms. Menopause 9: 145-150. 